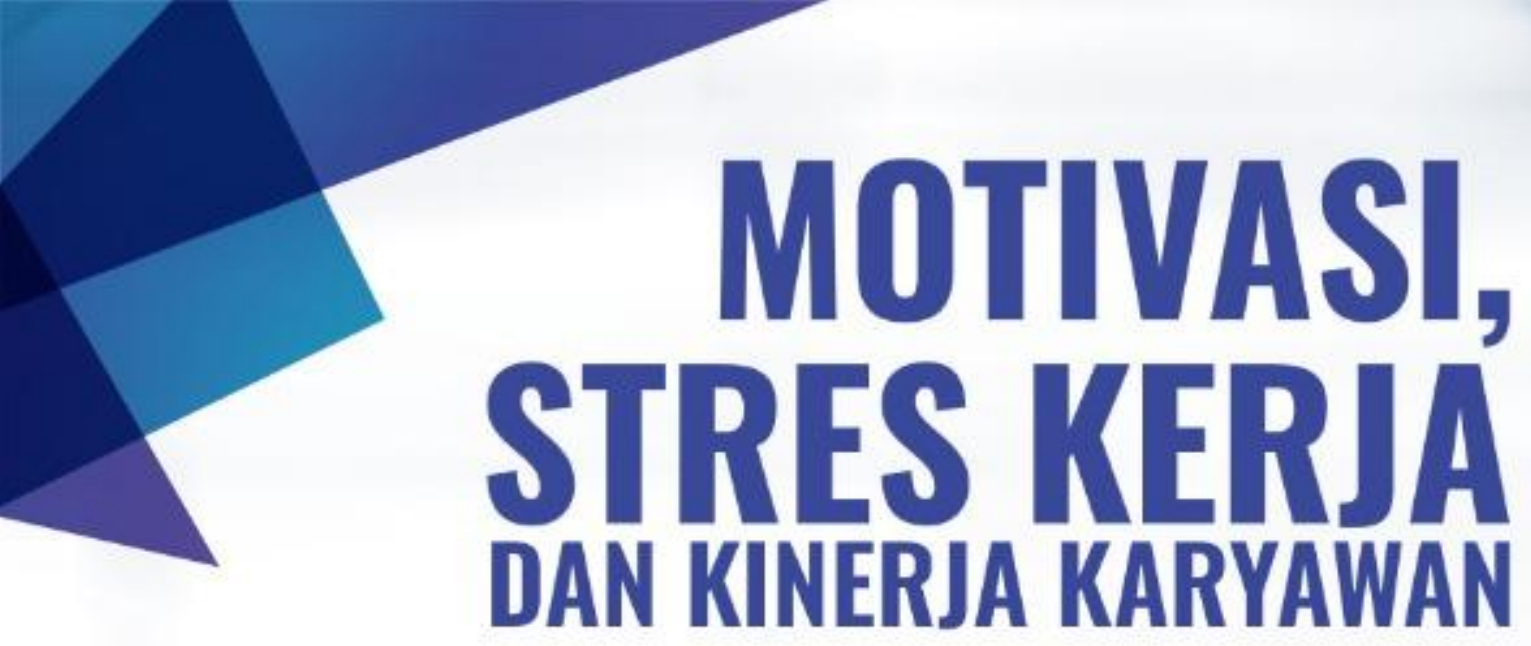

Kinerja karyawan merupakan faktor penting dalam kesuksesan perusahaan dan setiap bentuk usaha. Dengan kinerja yang baik, maka produktivitas akan meningkat dan layanan maupun produk yang diberikan kepada konsumen akan baik. Walaupun menjadi salah satu kunci kesuksesan dalam berbisnis, peningkatan kinerja karyawan bukanlah sesuatu yang mudah. Hal ini karena banyak faktor yang mempengaruhinya dan setiap tempat memiliki keunikan sendiri. Tidak setiap kasus di suatu perusahaan akan sama dengan kasus di perusahaan yang lain. Dari problematika ini, maka perlu adanya kajian serius tentang penyebab kinerja karyawan.

Buku ini mengungkap faktor dominan berupa motivasi dan stres kerja dalam kaitannya dengan kinerja karyawan. Dua faktor tersebut memberikan andil dalam peningkatan maupun penurunan kinerja karyawan. Oleh karena itu, bagi siapa saja yang ingin meningkatkan kinerja karyawan, maka perlu mempelajari faktor motivasi dan stress kerja tersebut. Buku ini disusun oleh akademisi yang ahli dalam manajemen sumber daya manusia. Dengan bahasa yang lugas dan jelas, penulis mengungkap bagaimana kinerja karyawan dibentuk melalui motivasi dan pengelolaan stress kerja yang baik.
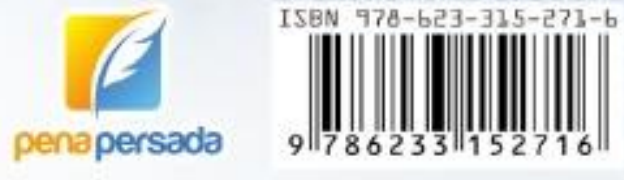

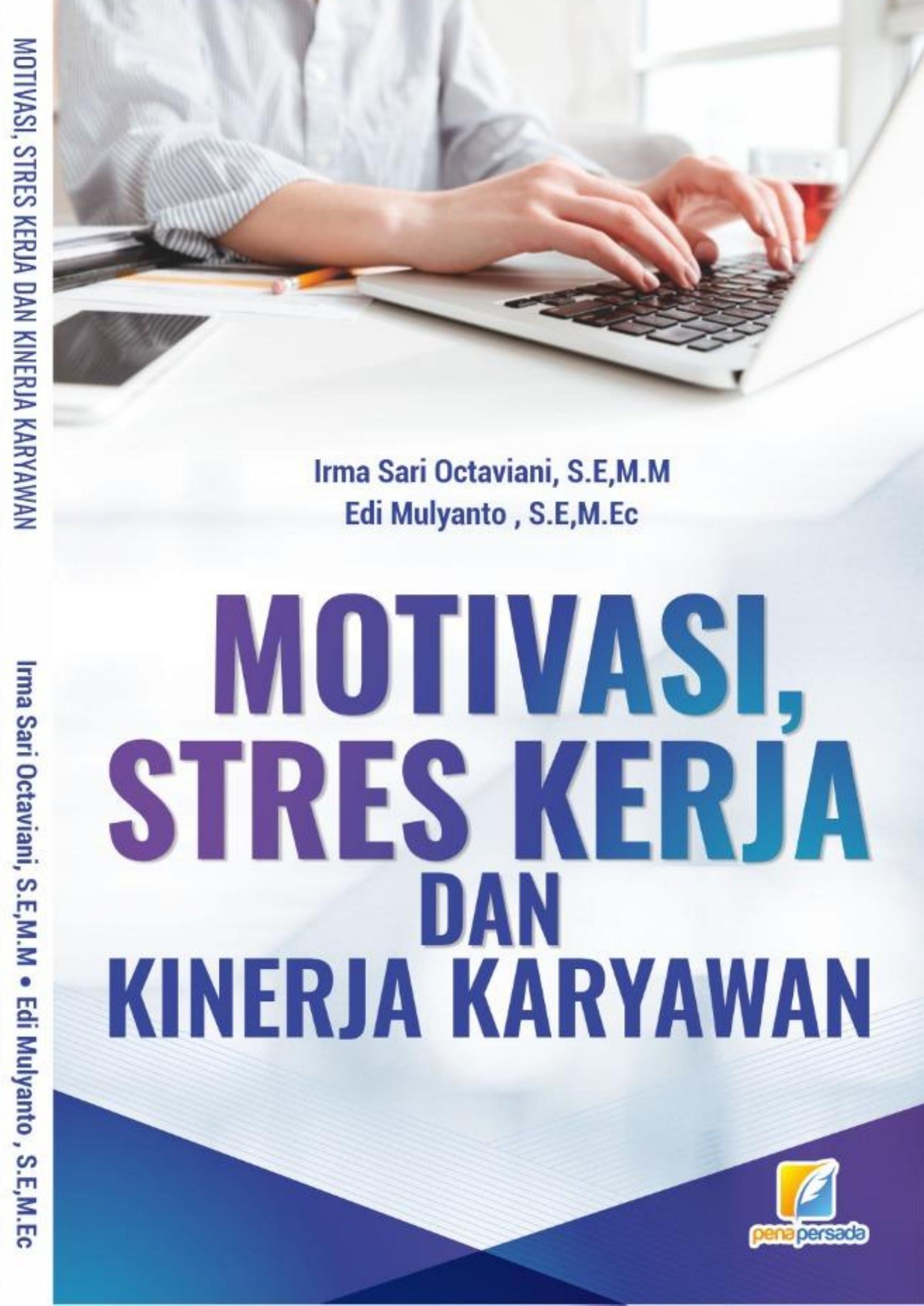




\title{
MOTIVASI, STRES KERJA DAN KINERJA KARYAWAN
}

\author{
Irma Sari Octaviani, S.E,M.M
}

Edi Mulyanto , S.E,M.Ec

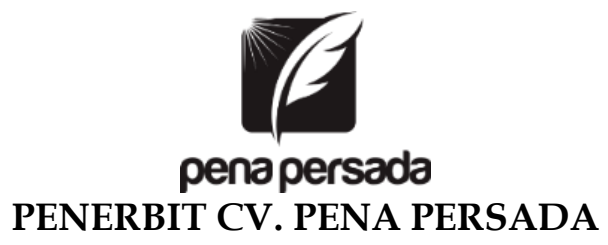




\title{
MOTIVASI, STRES KERJA DAN KINERJA KARYAWAN
}

\author{
Penulis: \\ Irma Sari Octaviani, S.E,M.M \\ Edi Mulyanto, S.E,M.Ec \\ ISBN : 978-623-315-271-6 \\ Editor: \\ Wiwit Kurniawan \\ Design Cover : \\ Retnani Nur Briliant \\ Layout : \\ Hasnah Aulia \\ Penerbit CV. Pena Persada \\ Redaksi : \\ Jawa Tengah \\ Email : penerbit.penapersada@gmail.com \\ Website : penapersada.com Phone : (0281) 7771388 \\ Anggota IKAPI \\ All right reserved \\ Cetakan pertama : 2021
}

Jl. Gerilya No. 292 Purwokerto Selatan, Kab. Banyumas

Hak Cipta dilindungi oleh undang-undang. Dilarang memperbanyak karya tulis ini dalam bentuk apapun tanpa izin penerbit 


\section{KATA PENGANTAR}

Puji syukur saya panjatkan kepada Tuhan Yang Maha Esa, karena atas berkat dan rahmat-Nya, saya dapat menyelesaikan buku ini. Penulisan buku merupakan buah karya dari pemikiran penulis yang diberi judul "MOTIVASI, STRES KERJA DAN KINERJA KARYAWAN ". Saya menyadari bahwa tanpa bantuan dan bimbingan dari berbagai pihak sangatlah sulit bagi saya untuk menyelesaikan karya ini. Oleh karena itu, saya mengucapkan banyak terima kasih pada semua pihak yang telah membantu penyusunan buku ini. Sehingga buku ini bisa hadir di hadapan pembaca.

Penulis menyadari bahwa buku ini masih jauh dari kesempurnaan. Oleh karena itu kritik dan saran yang membangun sangat dibutuhkan guna penyempurnaan buku ini. Akhir kata saya berharap Tuhan Yang Maha Esa berkenan membalas segala kebaikan semua pihak yang telah membantu. Semoga buku ini akan membawa manfaat bagi pengembangan ilmu pengetahuan. 


\section{DAFTAR ISI}

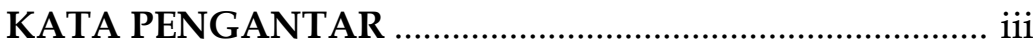

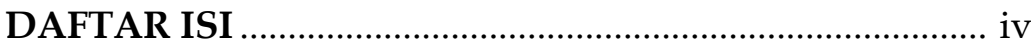

BAB I PERSOALAN KINERJA KARYAWAN

A. Pentingnya sebuah motivasi bagi karyawan perusahaan ........................................................... 1

B. Menurunnya Kinerja Karyawan ............................... 3

BAB II MANAJEMEN

A. Pengertian Manajemen .............................................. 7

B. Teori- Teori Manajemen .............................................. 9

C. Perkembangan Teori Manajemen ............................ 19

D. Dasar- Dasar Manajemen ......................................... 21

E. Sistem-Sistem Manajemen .......................................... 21

F. Fungsi-Fungsi Manajemen........................................ 22

G. Unsur-Unsur Manajemen........................................ 23

BAB III MANAJEMEN SUMBER DAYA MANUSIA

A. Pengertian Manajemen Sumber Daya Manusia..... 27

B. Pendekatan Manajemen Sumber Daya Manusia (MSDM) ................................................. 29

C. Ruang Lingkup Manajemen Sumber Daya Manusia 32

1. Landasan Prinsip Manajemen Sumber Daya Manusia .......................................................... 33

2. Posisi Dan Struktur Manajemen Sumber Daya Manusia 34

3. Tanggung Jawab Kunci Manajemen Sumber Daya Manusia

4. Bisnis Kecil dan Manajemen Sumber Daya Manusia 
BAB IV FAKTOR YANG MENENTUKAN KINERJA KARYAWAN
A. Faktor Motivasi 44
B. Teori Motivasi Pekerja. 53
C. Bagaimana Motivasi Kerja Mempengaruhi Kinerja.....
D. Faktor Stres Kerja 67

\section{BAB V KINERJA KARYAWAN}

A. Sumber Daya Manusia .............................................. 95

B. Pengertian Kinerja ................................................... 97

C. Tujuan Penilaian Kinerja............................................ 102

D. Indikator Kinerja ..................................................... 102

BAB VI OPTIMALISASI KINERJA KARYAWAN

A. Arti Sebenarnya dari "Pengoptimalan Tenaga Kerja". 105

B. Mengapa Harus Mencoba Pengoptimalan Karyawan 107

C. Strategi Optimalisasi ............................................... 109

DAFTAR PUSTAKA 113 


\section{MOTIVASI, STRES KERJA DAN KINERJA KARYAWAN}




\section{BAB I \\ PERSOALAN KINERJA \\ KARYAWAN}

\section{A. Pentingnya sebuah motivasi bagi karyawan perusahaan}

Manajemen sumber daya manusia merupakan bagian dari manajemen keorganisasian yang memfokuskan diri pada unsur sumber daya manusia atau bisa di katakan suatu proses yang terdiri dari perencanaan, pengorganisasian, pemimpin dan pengendalian kegiatan sumber daya manusia dan sumber daya manusia lainnya untuk mencapai tujuan yang telah ditetapkan.

Apalagi di era kompetitif sekarang persaingan perusahaan semakin tajam. sehingga sumber daya manusia (SDM) dituntut untuk terus-menerus mampu mengembangkan diri secara proaktif. Untuk mencapai kinerja yang tinggi seseorang atau karyawan harus memiliki motivasi juga untuk berprestasi dan unggul dalam pekerjaannya.

Pentingnya sebuah motivasi bagi karyawan perusahaan, bisa dilihat dan dinilai sejauh mana tanggung jawab yang dilaksanakan dan dicapai pada setiap karyawan. Setiap karyawan diharapkan memiliki motivasi yang tinggi untuk mendukung kemajuan sebuah 
perusahaan. Menurut Anwar P.M dalam Ridhotullah, S (2015:291) “Motivasi merupakan kondisi atau energi yang mengerakkan diri pegawai yang terarah atau tertuju untuk mencapai tujuan oraganisasi perusahaan." Motivasi semakin penting karena atasan membagikan pekerjaan pada bawahannya untuk dikerjakan dengan baik dan terintegrasi kepada tujuan yang di inginkan. Kurangnya motivasi karyawan bisa dilihat dari kedisiplinan dia dalam bekerja, ketepatan dia dalam menyelesaikan pekerjaan dan keinginan untuk berprestasi dalam bekerja. Jika karyawan tidak memiliki motivasi, karyawan dianggap tidak bisa memenuhi tugasnya sebagai pekerja.

Faktor lain yang kurang baik yakni, menurunnya karyawan dalam beprestasi karena kurangnya motivasi untuk maju dan tingkat stres yang dialami setiap karyawan. Usaha dalam meningkatkan kinerja karyawan ialah dengan memperhatikan stres dan motivasi yang ada dalam diri karyawan tersebut. Stres merupakan suatu kondisi keadaan seseorang mengalami ketegangan karena adanya kondisi yang mempengaruhinya, kondisi tersebut dapat diperoleh dari dalam dan luar diri. Stres dapat menimbulkan dampak yang negatif terhadap keadaan psikologis dan biologis bagi karyawan.

Menurut Sunyoto (2015:54) "stres merupakan sesuatu yang menyangkut interaksi antara individu dan lingkungan yaitu interaksi antara simultan dan respon. Jadi stres adalah konsekuensi setiap tindakan dan situasi lingkungan yang menimbulkan tuntutan psikologi dan fisik yang berlebihan." Stres kerja akan muncul bila 
terdapat kesenjangan antara kemampuan individu dengan tuntutan-tuntutan dari pekerjaannya

Namun disisi lain stres kerja juga bisa dipengaruhi dengan masalah perusahaan dan mengakibatkan kinerja yang dihasilkan tidak maksimal.

\section{B. Menurunnya Kinerja Karyawan}

Keberhasilan suatu perusahaan tak lepas dari kinerja karyawan. Salah satu yang mempengaruhi tingkat keberhasilan perusahaan itu sendiri adalah kinerja karyawan. Memiliki karyawan dengan kinerja yang baik merupakan dambaan setiap perusahaan. Menurut Sutrisno (2015:172) “Kinerja karyawan adalah hasil kerja karyawan dilihat dari aspek kualitas, kuantitas, waktu kerja, dan kerja sama untuk mencapai tujuan yang sudah ditetapkan organisasi." Semuanya akan berjalan dengan optimal jika di dukung dengan sumber daya manusia yang mumpuni dan berkualitas.

Meskipun terlihat jelas, kualitas kerja yang menurun adalah salah satu tanda pertama penurunan keterlibatan. Ketika karyawan tidak lagi merasa terhubung dengan perusahaan mereka, mereka sering kesulitan untuk memberikan upaya terbaik mereka. Jika seorang karyawan mulai menunjukkan tingkat kualitas kerja yang lebih rendah, penting untuk menangani situasi tersebut dengan tepat. Daripada menghukum atau memberikan peringatan, cobalah berdiskusi dan mencari tahu penyebab sebenarnya dari masalah tersebut. Bekerja dengan seorang karyawan untuk mengatasi masalah biasanya jauh lebih efektif daripada ceramah atau hukuman yang membuat marah. Evaluasi kinerja masa 
lalu mereka dan coba temukan di mana kualitas pekerjaan mulai menurun. Komunikasikan secara jujur tentang kekhawatiran Anda dan bekerja sama untuk menemukan solusi yang dipersonalisasi.

Ketika seorang pemberi pengaruh yang keluar tibatiba berhenti berbicara, itu hampir selalu merupakan tanda penurunan keterlibatan karyawan. Karyawan yang blak-blakan cenderung bersemangat dan persuasif, dan dapat menimbulkan perasaan negatif di seluruh organisasi. Penting bagi seseorang dari manajemen atau HR untuk memahami perubahan kebijakan atau tindakan apa yang memicu perubahan perilaku ini. Meskipun karyawan, tentu saja, tidak selalu setuju dengan keputusan perusahaan, pelepasan keterlibatan sering kali berasal dari kesalahpahaman. Cobalah untuk berbicara dengan karyawan Anda dan ciptakan perspektif mengapa keputusan tertentu dibuat. Setelah mengatasi masalah dan menghilangkan kesalahpahaman, dia bahkan dapat menjadi juru bicara untuk perubahan atau tindakan kebijakan, membantu karyawan lain tetap terlibat dan aktif.

Keengganan untuk bekerja dengan rekan-rekan mereka adalah tanda peringatan penting lainnya dari penurunan keterlibatan karyawan. Keengganan ini dapat berasal dari satu karyawan, tim, cabang, atau bahkan dari seluruh organisasi. Memahami partisipasi karyawan dan upaya kolaborasi membantu pemberi kerja memahami sentimen penting dalam organisasi, terutama ketika ada penurunan tingkat keterlibatan yang tiba-tiba atau tidak terduga. Fase yang berkepanjangan dari pengurangan keterlibatan sosial tidak boleh dibiarkan begitu saja dan 
perusahaan harus melakukan yang terbaik untuk menilai kekhawatiran secepat mungkin.

Karyawan yang tidak terlibat mungkin bekerja dengan cemerlang, melaksanakan tujuan, dan menerima evaluasi yang luar biasa, tetapi kinerja kerja tidak boleh dianggap sebagai satu-satunya indikator tingkat keterlibatan. Meskipun menghindari permainan perusahaan atau acara sosial yang terorganisir tidak selalu berarti mengurangi keterlibatan karyawan, itu bisa menjadi tanda ketidakbahagiaan atau ketidaktertarikan pada budaya perusahaan. Hal ini terutama terjadi jika karyawan tersebut sebelumnya aktif dan terlibat dalam aktivitas kantor. Meskipun kinerja mereka mungkin tidak menurun, ketidaktertarikan pada budaya perusahaan tetap penting dan dapat memainkan peran utama dalam kebahagiaan dan kepuasan kerja karyawan Anda.

Ketika karyawan secara mental terputus dari perusahaan, menjadi lebih sulit untuk melihat rekan kerja dan manajer sebagai bagian dari tim mereka. Akibatnya, karyawan menjadi kurang sabar dan kurang pengertian terhadap orang lain di tempat kerja. Gangguan kecil mungkin mulai terasa seperti menambah masalah, terutama jika alasan sebenarnya untuk melepaskan diri belum dibahas. Personel SDM atau manajernya masingmasing perlu turun tangan dan meredakan situasi dengan mengatasi masalah yang sebenarnya. Namun, iritasi yang meningkat mungkin juga disebabkan oleh masalah yang tidak berhubungan dengan pekerjaan. Anggota SDM harus melakukan yang terbaik untuk mengamati dan berkonsultasi dengan karyawan tersebut untuk 
memahami dan mengatasi masalah terkait pekerjaan yang mendasarinya.

Pengetahuan tentang kinerja karyawan dapat langsung mengingatkan admin tentang perubahan kinerja karyawan, membantu mereka mengatasi masalah saat itu terjadi. Saat mendekati karyawan tentang kinerjanya, pastikan untuk tidak melakukan manajemen mikro. Dekati situasi dengan tujuan bekerja sama dengan karyawan untuk mengidentifikasi masalah dan mencari solusi.

Karyawan yang terlibat bersemangat tentang pekerjaan dan peran yang mereka mainkan dalam sebuah organisasi. Mereka mengambil tantangan baru dengan antusias dan melihatnya sebagai peluang untuk menjadi kreatif dan menunjukkan kemampuan mereka. Ketika karyawan mengalami penurunan keterlibatan, tantangan menjadi beban daripada motivasi. Ini terutama benar ketika karyawan selalu cepat bertindak dan mengambil tugas baru di masa lalu. Ketika seorang karyawan tidak menunjukkan antusiasmenya yang khas, itu adalah indikasi yang jelas bahwa sesuatu sedang terjadi. Bicaralah dengan karyawan tentang kepuasan kerja mereka atau tanyakan tentang proyek mana yang akan mereka minati berdasarkan bakat dan keterampilan mereka. 


\section{BAB II \\ MANAJEMEN}

\section{A. Pengertian Manajemen}

Manajemen merupakan alat untuk mencapai tujuan yang diinginkan. Pengertian manajemen merupakan seni melakukan suatu pekerjaan melalui orang-orang lain untuk suatu tujuan tertentu. Manajemen yang baik akan memudahkan terwujudnya tujuan perusahaan, karyawan yang baik akan memudahkan tujuan perusahaan, karyawan, dan masyarakat. Dengan manajemen, daya guna dan hasil guna unsur-unsur manajemen akan dapat ditingkatkan.

Manajemen berasal dari kata to manage yang artinya mengatur. Timbul pertanyaan tentang : apa yang diatur, apa tujuannya diatur, mengapa harus diatur, siapa yang mengatur, dan bagaimana mengaturnya.

1. Yang diatur adalah semua unsur manajemen, yakni 6 $\mathrm{M}$.

2. Tujuannya diatur adalah agar $6 \mathrm{M}$ lebih berdaya guna dan berhasil guna dalam mewujudkan tujuan. 
3. Harus diatur supaya $6 \mathrm{M}$ itu bermanfaat optimal, terkoordinasi dan terintegrasi dengan baik dalam menunjang terwujudnya tujuan organisasi.

4. Yang mengatur adalah pemimpin dengan kepemimpinanya yaitu pimpinan pucak, manajer madya, dan supervisi.

5. Mengaturnya adalah dengan melakukan kegiatan uruturutan fungsi manajemen tersebut.

Definisi manajemen menurut ahli :

1. Menurut M. Manullang (2018:2) “ manajemen adalah seni dan ilmu perencanaan, pengorganisasian, penyusunan, pengarahan dan pengawasan sumber daya manusia untuk mencapai tujuan yang sudah ditetapkan."

2. Menurut Harold Koontz dan Cyril O'Donnel dalam buku Malayu S.P Hasibuan (2018:3) "management is getting things done trough people. In bringing about this coordinating of group activity, the manager, as a manager plans, organize, staffs, direct and control the activities other people." (Manajemen adalah usaha mencapai suatu tujuan tertentu melalui kegiatan orang lain. Dengan demikian manajer mengadakan koordinasi atas sejumlah aktivitas orang lain yang meliputi perencanaan, pengorganisasian, penempatan, pengarahan, dan pengendalian).

3. Menurut Malayu S.P. Hasibuan (2019:1) menyatakan "manajemen adalah ilmu dan seni mengatur proses pemanfaatan sumber daya manusia dan sumbersumber lainnya secara efektif dan efisien untuk mencapai suatu tujuan tertentu"

Dari penjelasan definisi diatas, dapat ditarik kesimpulan bahwa manajemen merupakan suatu proses 
yang terdiri dari kegiatan sperti perencanaan, pengorganisasian, penggerakan dan pengendalian/ pengawasan, yang dilakukan untuk menentukan dan mencapai tujuan yang telah ditetapkan melalui pemanfaatan sumberdaya manusia dan sumberdaya lainnya.

\section{B. Teori-Teori Manajemen}

Dalam ilmu sosial, perkembangan minat pada penelitian tentang sistem kapitalisme menjadi inti dari karya intelektual Max Weber. Jika Weber mengatakan bahwa karakteristik kapitalisme merupakan bentuk tunggal dari organisasi privat dalam sistem ekonomi pasar, maka karakteristik lain yang mucul dalam perkembangan kapitalisme adalah pola pikir manajerial dan munculnya kelas sosial baru yang bernama manajer.

Di sini kita temukan bahwa pola pikir manajerial dan kelas manajer muncul dalam sebuah sistem ekonomi kapitalis yang ditopang oleh industrialisme abad 19 di dunia barat. Menurut sejarawan bisnis Alfred Chandler, teori manajemen bisa dikatakan muncul pada akhir abad 19 ketika bisnis dan industri berkembang pesat di Amerika Serikat. Apa itu teori manajemen?

Teori manajemen bisa dipahami sebagai sebuah proses sosial dan figur sosial. Sebagai proses sosial, teori manajemen adalah proses bagaimana organisasi bisa berjalan secara efektif dan efisien. Sebagai figur sosial, teori manajemen adalah kelompok sosial, biasanya terdiri dari eksekutif dan manajer, yang bekerja untuk 
menciptakan efektivitas dan efisiensi organisasi demi mencapai tujuan organisasi.

Lahirnya teori manajemen tidak lepas dari sejarah pemikiran manajerial yang meniliki tiga kontributor utama, yaitu praktisi, konsultan dan akademisi. Kontribusi praktisi dan konsultan pada pemikiran manajerial dan teori manajemen lebih cenderung bersifat preskriptif dan praktis. Sedangkan kontribusi akademisi pada teori manajemen lebih cenderung analitis.

Untuk lebih memahami teori manajemen secara komprehensif, saya akan memaparkan beberapa tokoh perintis teori manajemen di dunia. Sebelumnya, periode perkembangan pemikiran menajerial perlu dipaparkan agar pembaca mendapat gambaran sistematis tentang teori manajemen.

Perkembangan manajemen yang sangat cepat melalui studi di perguruan tinggi memunculkan teoriteori manajemen dari berbagai aliran.

Perkembangan manajemen yang sangat cepat melalui studi di perguruan tinggi memunculkan teoriteori manajemen dari berbagai aliran. Teori tersebut dapat dikelompokkan ke dalam enam aliran :

\section{Aliran Managemen Ilmiah}

Teori Manajemen Ilmiah muncul sebagaian dari kebutuhan untuk meningkatkan produktivitas. Di awal abad keduapuluh, terutama Amerika Serikat, tenaga kerja trampil amat terasa kuirang, satu satunya cara untuk 
meningkatkan produktivitas adalah menaikkan efisiensi pekerja.

Frederick W. Taylor (1856-1915)

Frederick W. Taylor dikenal dengan manajemen ilmiahnya dalam upaya meningkatkan produktivitas. Gerakannya yang terkenal adalah gerakan efisiensi kerja. Taylor membuat prinsip-prinsip yang menjadi intinya manajemen ilmiah yang terkenal dengan rencana pengupahan yang menghasilkan turunnya biaya dan meningkatkan produktivitas, mutu, pendapatan pekerjaan dan semangat kerja karyawan. Adapun filsafat Taylor memiliki 4 prinsip yang ditetapkan yaitu :

a) Pengembangan manajemen ilmiah secara benar.

b) Pekerjaan diseleksi secara ilmiah dengan menempatkan pekerjaan yang cocok untuk satu pekerjaan.

c) Adanya pendidikan dan pengambangan ilmiah dari para pekerja.

d) Kerjasama yang baik antara manajemen dengan pekerja.

Dalam menerapkan ke-empat prinsip ini, beliau menganjurkan perlunya revolusi mental di kalangan manajer dan pekerja. Adapun prinsip-prinsip dasar menurut Taylor mendekati ilmiah adalah :

1. Adanya ilmu pengetahuan yang menggantikan cara kerja yang asal-asalan.

2. Adanya hubungan waktu dan gerak kelompok.

3. Adanya kerja sama sesama pekerja, dan bukan bekerja secara individual. 
4. Bekerja untuk hasil yang maksimal.

5. Mengembangkan seluruh karyawan hingga taraf yang setinggi-tingginya.

Henry L Gant (1861 -1919)

Henry L Gant menekankan pentingnya mengembangkan minat hubungan timbal balik antara manajemen dan para karyawan, yaitu kerja sama yang harmonis. Henry beranggapan bahwa unsur manusia sangat penting sehingga menggaris bawahi pentingnya mengajarkan, mengembangkan pengertian tentang sistem pada pihak karyawan dan manajemen, serta perlunya penghargaan dalam segala masalah manajemen.

a) Gant membuat ide baru, setiap pekerja yang dalam sehari berhasil menyelesaikan tugas yang dibebankan kepadanya akan menerima bonus sebesar 50 sen.

b) Kemudian ia menambahkan motivasi kedua, supervisor akan mendapat bonus tambahan bila semua pekerja mencapai standar tersebut.

c) Gant memelopori sistem pencatatan dengan bagan untuk jadwal produksi (Gant Chart)

d) Meninggalkan sistem tarif berbeda karena dianggap terlalu kecil memberikan dampak motivasional.

Frank B. Gilbreth 1868-1924 dan Lilian Gilbreth 1878-1972 Suami istri ini selain mempelajari masalah gerak dan kelelahan, juga tertarik dengan usaha membantu pekerja menampilkan potensinya secara penuh sebagai makhluk manusia. Setiap langkah yang dapat menghasilkan gerak dapat mengurangi kelelahan. 
Mereka juga terkenaI dengan tiga peran dari setiap pekerja yaitu sebagai pelaku, pelajar dan pelatihan yang senantiasa mencari kesempatan baru, atau terkenal dengan konsep "three position plan of promotion". Banyak manfaat dan jasa yang diberikan oleh manajemen ilmiah, namun satu hal penting dilupakan oleh manajemen ini, yaitu kebutuhan social manusia dalam berkelompok, karena terlalu mengutamakan keuntungan dan kebutuhan ekonomis dan fisik perusahaan dan pekerjaan. Aliran ini melupakan kepuasan pekerjaan pekerja sebagai manusia biasa. Perhatian Lilian Gilbreth tertuju pada aspek manusia dari kerja dan perhatian suamianya pada efisiensi -yaitu usaha untuk menemukan cara satu-satunya yang terbaik dalam melaksanakan tugas tertentu. Dalam menerapkan prinsipprinsip manajemen ilmiah, harus memandang para pekerja dan mengerti kepribadian serta kebutuhan mereka. Ketidakpuasan di antara pekerja karena kurang adanya perhatian dari pihak manajemen terhadap pekerja.

\section{Aliran Teori Organisasi Klasik}

Aliran ini mendefinisikan manajemen sesuai dengan fungsi-fungsi manajemen. Perhatian dan kemampuan manajemen diarahkan pada penerapan fungsi-fungsi tersebut.

Henry Fayol (1841 -1925)

Henry Fayol berpendapat bahwa praktek manajemen yang mantap mempunyai pola tertentu yang dapat diidentifikasi dan dianalisa, yaitu :

a) Pembagian kerja (Division of labor), yaitu sernakin mengkhusus manusia dalam 